\title{
Environmentally clean access to Antarctic subglacial aquatic environments
}

\author{
ALEXANDER B. MICHAUD 10 1,2, TRISTA J. VICK-MAJORS ${ }^{2,3}$, AMANDA M. ACHBERGER 4,5 , \\ MARK L. SKIDMORE ${ }^{6}$, BRENT C. CHRISTNER ${ }^{5,7}$, MARTYN TRANTER ${ }^{8}$ and JOHN C. PRISCU ${ }^{2}$ \\ ${ }^{1}$ Bigelow Laboratory for Ocean Sciences, East Boothbay, ME, USA \\ ${ }^{2}$ Department of Land Resources and Environmental Sciences, Montana State University, Bozeman, MT, USA \\ ${ }^{3}$ Department of Biological Sciences, Michigan Technical University, Houghton, MI, USA \\ ${ }^{4}$ Department of Oceanography, Texas A\&M University, College Station, TX, USA \\ ${ }^{5}$ Department of Biological Sciences, Louisiana State University, Baton Rouge, LA, USA \\ ${ }^{6}$ Department of Earth Sciences, Montana State University, Bozeman, MT, USA \\ ${ }^{7}$ Department of Microbiology and Cell Science, Biodiversity Institute, University of Florida, Gainesville, FL, USA \\ ${ }^{8}$ Bristol Glaciology Centre, School of Geographical Sciences, University of Bristol, Bristol, UK \\ a.b.michaud@gmail.com
}

\begin{abstract}
Subglacial Antarctic aquatic environments are important targets for scientific exploration due to the unique ecosystems they support and their sediments containing palaeoenvironmental records. Directly accessing these environments while preventing forward contamination and demonstrating that it has not been introduced is logistically challenging. The Whillans Ice Stream Subglacial Access Research Drilling (WISSARD) project designed, tested and implemented a microbiologically and chemically clean method of hot-water drilling that was subsequently used to access subglacial aquatic environments. We report microbiological and biogeochemical data collected from the drilling system and underlying water columns during sub-ice explorations beneath the McMurdo and Ross ice shelves and Whillans Ice Stream. Our method reduced microbial concentrations in the drill water to values three orders of magnitude lower than those observed in Whillans Subglacial Lake. Furthermore, the water chemistry and composition of microorganisms in the drill water were distinct from those in the subglacial water cavities. The submicron filtration and ultraviolet irradiation of the water provided drilling conditions that satisfied environmental recommendations made for such activities by national and international committees. Our approach to minimizing forward chemical and microbiological contamination serves as a prototype for future efforts to access subglacial aquatic environments beneath glaciers and ice sheets.
\end{abstract}

Received 8 October 2019, accepted 3 February 2020

Key words: environmental stewardship, forward contamination, hot-water drilling, Whillans Subglacial Lake

\section{Introduction}

The pristine aquatic habitats beneath the Antarctic ice sheet are of high scientific value (Priscu et al. 2008, Skidmore 2011) largely because they support microbial ecosystems in both the bulk water (Christner et al. 2014) and water-saturated sediments (Achberger et al. 2016, Michaud et al. 2017). These ecosystems have been suggested to be widespread beneath the Antarctic ice sheet and to represent our planet's largest wetland (Priscu et al. 2008). The biogeochemical activities of microorganisms at the ice sheet bed may be sufficient to contribute significantly to the global cycling of carbon, nitrogen and other elements (e.g. Wadham et al. 2010, Achberger et al. 2016, Vick-Majors et al. 2016, Michaud et al. 2017). Subglacial environments possess sedimentary packages that contain palaeoenvironmental and palaeoclimatic information on the history of the continent (Bentley et al. 2013). Furthermore, the direct measurement of geothermal heat flux and basal sliding at the bed of ice sheets is required in order to validate the parameterizations used in models of ice sheet mass balance (Engelhardt \& Kamb 1998, Fisher et al. 2015). In order to maintain environmental stewardship of the Antarctic environment, all endeavours that require direct access to wet portions of the ice sheet bed must consider drilling strategies that reduce forward contamination of the subglacial environment (Doran \& Vincent 2011).

The base of the Antarctic ice sheet has been accessed by mechanical drilling that incorporates hydrocarbon-based drilling fluids (e.g. Bulat 2016) and hot-water melting (e.g. Rack 2016). Mechanical drilling can be deleterious 


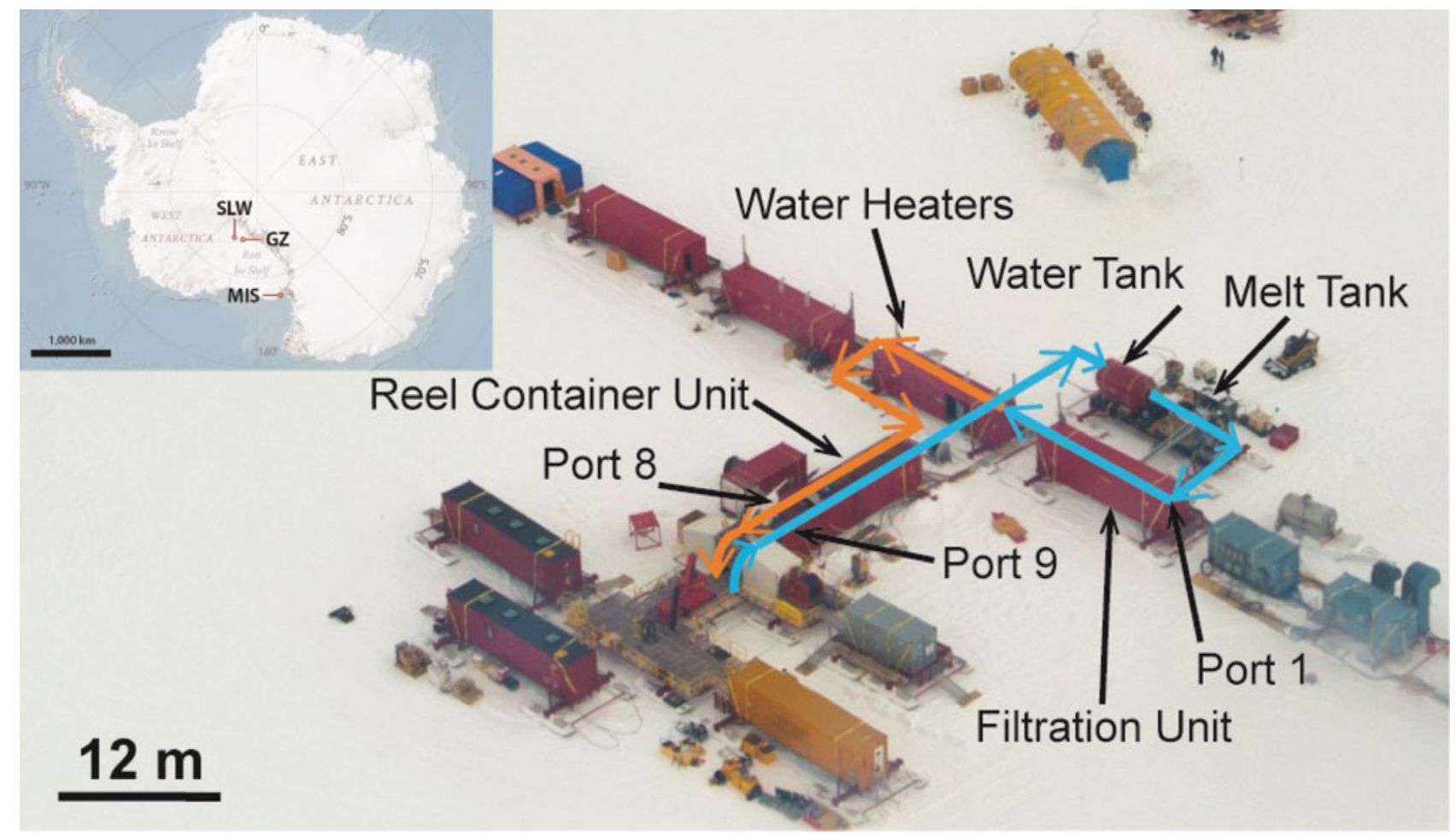

Fig. 1. Whillans Subglacial Lake (SLW) hot-water drill setup with sampling ports and drill system components labelled. The orange line indicates hot, down-borehole water in the direction of the arrowheads on the line. The blue line indicates cold water coming up the borehole from the return water pump in the direction of the arrowheads on the line. The inset map indicates the three field sites where clean access samples were taken. Inset map by Brad Herried, Polar Geospatial Center. Camp overview photograph courtesy of J.T. Thomas. GZ = grounding zone, MIS = McMurdo Ice Shelf.

to the environment because it requires organic drilling fluids and densifiers (e.g. kerosene-based fluids with density additives such as chlorofluorocarbons (CFCs), ethanol and n-butyl acetate; Talalay \& Gundestrup 2002). Drilling fluid is required to prevent lithostatic pressure from causing plastic collapse of the borehole, to lubricate the drill head and to remove ice chips from the borehole (Talalay \& Gundestrup 2002). Controlling microbial contamination of hydrocarbon-based drilling fluids is difficult (Christner et al. 2005, Bulat 2016, Alekhina et al. 2018). Hydrocarbon-based drilling fluids are also not ideal for accessing subglacial habitats due to concerns of chemical contamination (Talalay \& Gundestrup 2002). For example, mechanical drilling using a kerosene-based fluid densified with CFCs was used to access Vostok Subglacial Lake, but the frozen lake water recovered by coring was heavily contaminated with the kerosene-based and CFC-laden drilling fluid, which compromised scientific interpretation (Alekhina et al. 2018). Hot-water drilling was used to access Whillans Subglacial Lake (SLW; West Antarctica) (Tulaczyk et al. 2014), a subglacial lake in the Grímsvötn caldera (Iceland) (Gaidos et al. 2004), the bed of Kamb Ice Stream (West Antarctica) (Engelhardt et al. 2000), a sub-ice shelf marine cavity (West
Antarctica) (Vick-Majors et al. 2015) and a surge-type valley glacier (Alaska) (Truffer et al. 1999). A distinct advantage of hot-water drilling is the capacity to remove microbial contaminants in the drill water (e.g. filtration, ultraviolet (UV) and heat treatment; Priscu et al. 2013) and not to introduce exogenous chemicals when accessing the sub-ice environment. Regardless of the method used to access Antarctic subglacial aquatic environments, environmental stewardship and the integrity of samples recovered are important considerations (National Research Council 2007, Doran \& Vincent 2011).

The Whillans Ice Stream Subglacial Access Research Drilling (WISSARD) project developed and tested a high-capacity clean-water system as an integral component of a hot-water drill system (Priscu et al. 2013, Rack et al. 2014). The WISSARD hot-water drill used mechanical filtration, short-wavelength UV radiation and pasteurization to reduce the concentration of microorganisms and chemical impurities in the drill water. This system was tested in controlled laboratory experiments in order to demonstrate the efficacy of each component before its use in Antarctica (Priscu et al. 2013). Here, we report data from the clean access system of the WISSARD hot-water drill during three separate 

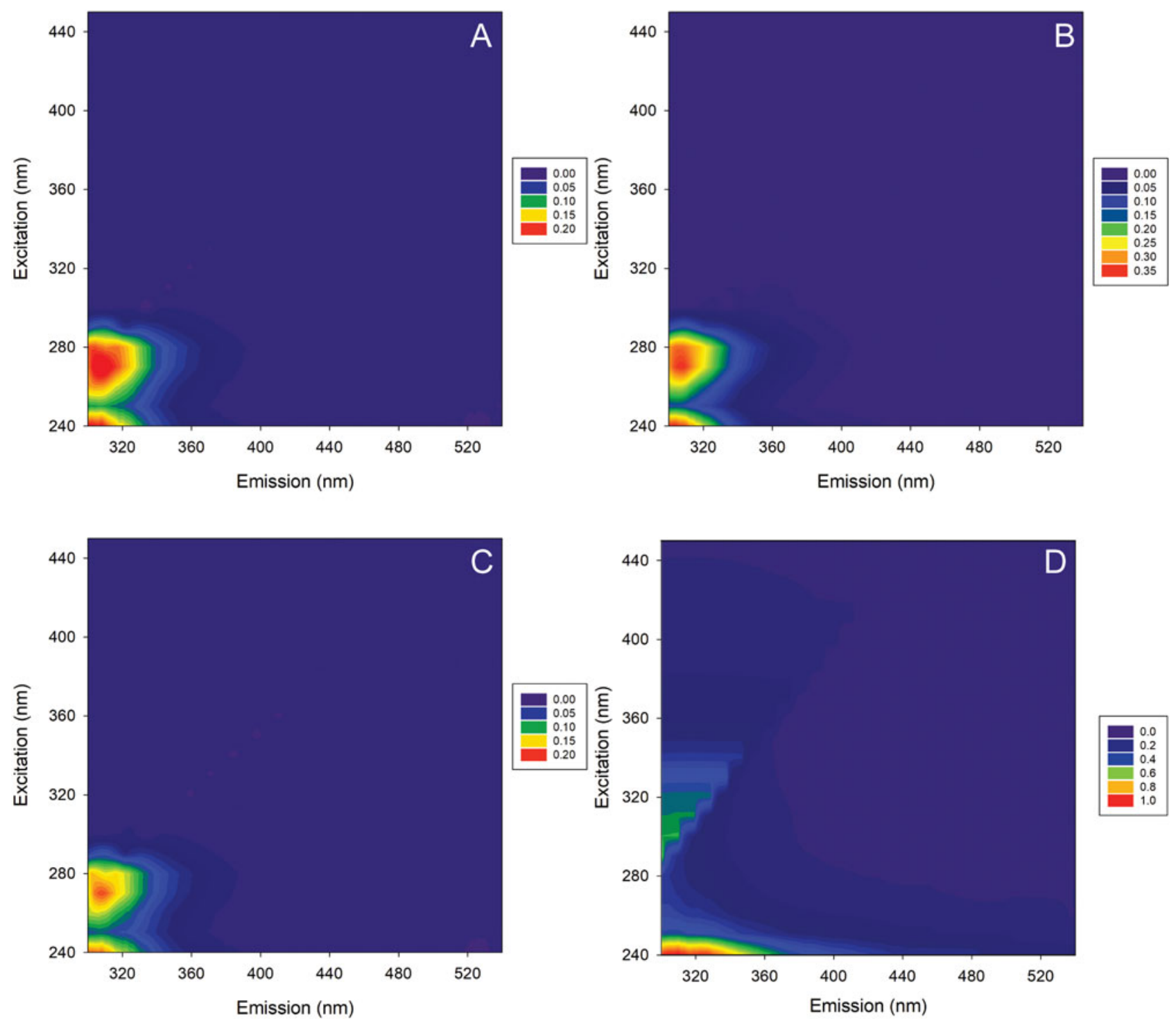

Fig. 2. Excitation emission matrix spectroscopy contour plot from a. clean access sampling port 1, b. clean access sampling port 8 , c. borehole cast and d. Subglacial Lake Whillans water column. c. and d. are modified from Vick-Majors et al. (2020).

drilling campaigns that accessed Antarctic subglacial aquatic environments. We offer recommendations for future projects planning scientific access to Antarctic subglacial aquatic environments based on the results and experiences from these campaigns.

\section{Methods}

\section{Drill system}

The hot-water drill system used during WISSARD (Rack et al. 2014) was plumbed to pass through a two-step filtration system and two-step UV irradiation. The filtration system consisted of a primary high-capacity, cartridge-style, pleated polypropylene filter that is 99.9\% efficient at retaining $2 \mu \mathrm{m}$ particles (Champion Process, Inc.) and a secondary high-flow, cartridge-style, pleated polyethersulfone filter with a $0.2 \mu \mathrm{m}$ absolute retention rating (Meissner Filtration Products, Inc.). The UV irradiation consisted of exposure to $185 \mathrm{~nm}$ (dosage > $40 \mathrm{~mW} \mathrm{~s}^{-1} \mathrm{~cm}^{-2}$ ) and $245 \mathrm{~nm}$ (dosage $>175 \mathrm{~mW} \mathrm{~s}^{-1} \mathrm{~cm}^{-2}$ ) UV radiation. After this initial treatment, the water was then pasteurized by heating to $\sim 90^{\circ} \mathrm{C}$ using Alkota $12257 \mathrm{~K}$ pressure washers (Fig. 1, 'Water Heaters') (Rack et al. 2014). Surface snow was used to prime the hot-water drill, and ice melt from the deepening borehole was subsequently used as the drilling fluid once drilling was underway, with snow melt used to supplement water loss. Figure 1 provides an overview of the various components of the drill (i.e. reservoir, filtration, UV modules, hot-water heaters and hose) and how they were integrated in the field (see also Priscu et al. 2013, Rack et al. 2014, Rack 2016). 
Sampling ports were plumbed between components in the drill system. Sampling port 1 was installed before the water entered the filtration units (Fig. 1) and is the same as is described in Priscu et al. (2013) and Achberger et al. (2016). Sampling port 8 was installed after filtration, irradiation and heating, but before the water entered the $1 \mathrm{~km}$ hose and travelled down the borehole to exit the drill head (Fig. 1, port 8) (Achberger et al. 2016). Sampling port 8 allowed access to sample water that was filtered, irradiated and pasteurized. There is no equivalent port in Priscu et al. (2013) because heaters were not installed during that test (see fig. 2 in Priscu et al. 2013). A return water pump was located in a separate, but connected, borehole $\sim 100 \mathrm{~m}$ beneath the surface, and this returned drilling water to the surface, where it once again went through filtration, UV treatment and heat pasteurization before being pumped back to the drill head. Samples of borehole return water were obtained via sampling port 9 (Fig. 1) (Achberger et al. 2016); sampling port 9 was not present in Priscu et al. (2013). Water returning from the borehole was temporarily stored in a holding tank and recirculated through the system (Fig. 1). This method was used at SLW and grounding zone (GZ) field sites; however, at the McMurdo Ice Shelf (MIS) site, the drill water was not recirculated.

\section{McMurdo Ice Shelf}

The drill and the filtration system were tested during the 2012-13 Antarctic field season at a site on the MIS $\left(77.8902^{\circ} \mathrm{S}, 167.0083^{\circ} \mathrm{E}\right.$; Fig. 1$), \sim 8 \mathrm{~km}$ from the margin of the MIS and $\sim 40 \mathrm{~km}$ from the sea ice-open water transition (Vick-Majors et al. 2015). Drilling operations were conducted at 50 gallons $\min ^{-1}$ for $5 \mathrm{~h}$ on 18 December 2012. There was $56 \mathrm{~m}$ of ice above an $872 \mathrm{~m}$ water column. In order to avoid contamination of the equipment with seawater before drilling at SLW, the water was not recirculated through the drill system, thus snowmelt was the only drill water constituent. We sampled ports 1 and 8 at three time points: the beginning of drilling operations (drill at $0 \mathrm{~m} ; \mathrm{T}_{0}$ ), halfway through the ice $\left(27 \mathrm{~m} ; \mathrm{T}_{1}\right)$ and just after breaking through the base of the ice shelf $\left(56 \mathrm{~m} ; \mathrm{T}_{2}\right)$. Samples were collected for measurement of cellular adenosine-5'-triphosphate (ATP) and cell density. The water was placed into acid-washed $(10 \% \mathrm{HCl})$, ultrapure $(18.2 \mathrm{Mohm})$ water-rinsed and combusted $\left(4 \mathrm{~h}, 450^{\circ} \mathrm{C}\right)$ glass bottles. Samples (101) for determination of the microbial community composition were collected in acid-washed and ultrapure water-rinsed carboys from sampling ports 1 and 8 at $\mathrm{T}_{2}$.

\section{Whillans Subglacial Lake}

The drill system was tractor-traversed to the SLW drill site $\left(84.240^{\circ} \mathrm{S}, 153.694^{\circ} \mathrm{W}\right.$; Fig. 1), and drilling operations were conducted from 22 to 27 January 2013 (Rack 2016). Samples were collected during drilling using a similar approach to the MIS test except that the drill water was recirculated using the return borehole pump that was located $\sim 100 \mathrm{~m}$ below the snow surface and was linked to the water reservoir in the main borehole (Rack 2016). Samples from ports 1 and 9 (Fig. 1) were collected at the beginning of drilling $\left(\mathrm{T}_{0}\right)$ and before SLW breakthrough $\left(\mathrm{T}_{1}\right)$. An acid-washed $(1 \% \mathrm{HCl})$, ultrapure water-rinsed, $3 \% \mathrm{H}_{2} \mathrm{O}_{2}$-cleaned Niskin bottle was used to sample the borehole water at a depth of $672 \mathrm{~m}$ below surface before breakthrough to SLW (Christner et al. 2014). We measured cellular ATP, cell density and fluorescent dissolved organic matter (FDOM) from the ports and the borehole water samples. The water samples were placed into acid-washed $(10 \% \mathrm{HCl})$, ultrapure $(18.2 \mathrm{Mohm})$ water-rinsed, combusted $\left(4 \mathrm{~h}, 450^{\circ} \mathrm{C}\right)$ glass bottles. Water for DNA-based microbial community composition was collected in acid-washed and ultrapure water-rinsed carboys from sampling ports 8 and 9 before breakthrough to SLW $\left(\mathrm{T}_{1}\right)$. Conductivity and $\mathrm{pH}$ samples were collected in sterile $50 \mathrm{ml}$ conical tubes.

\section{Grounding zone}

The hot-water drill was used to drill through $\sim 760 \mathrm{~m}$ of ice to access the marine water cavity beneath the Ross Ice Shelf from 7 to 9 January 2015 . The drill site $\left(-84.3354^{\circ} \mathrm{S}\right.$, $-163.6119^{\circ} \mathrm{W}$ ) was $2-5 \mathrm{~km}$ downstream from the Whillans Ice Stream grounding zone. The drill system configuration was identical to that at the SLW site, and the drill water was sampled from ports 1 and 8 at the beginning of drilling $\left(80 \mathrm{~m} ; \mathrm{T}_{0}\right)$ and at ice depths of $680 \mathrm{~m}\left(\mathrm{~T}_{1}\right)$ and $714 \mathrm{~m}\left(\mathrm{~T}_{2}\right)$. We measured the same analytes at the $\mathrm{GZ}$ as at SLW, except for FDOM.

\section{Leaching experiments}

Samples of the inner liner of the drill hose were tested for chemical tolerance at water temperatures of $90^{\circ} \mathrm{C}$. Three $10 \mathrm{~cm}$ segments of the hose liner were cut with a razor blade, cleaned with Alconox soap and rinsed six times with ultrapure (18.2 Mohm) water. Each hose segment was incubated in a separate, pre-combusted $\left(450^{\circ} \mathrm{C}\right.$ for $\sim 4 \mathrm{~h}$ ), foil-covered bottle containing $500 \mathrm{ml}$ of ultrapure $(18.2 \mathrm{Mohm})$ water at $90^{\circ} \mathrm{C}\left( \pm 5^{\circ} \mathrm{C}\right)$ for $106.5 \mathrm{~h}$. Triplicate bottles containing ultrapure (18.2 Mohm) water were incubated in parallel as controls. Samples $(\sim 20 \mathrm{ml})$ were collected from each incubation bottle at $12.5,24.3,36.5,59.5,87.5$ and $106.5 \mathrm{~h}$ in pre-combusted $40 \mathrm{ml}$ amber vials. The time zero samples represent ultrapure $(18.2 \mathrm{Mohm})$ water that was directly poured into the incubation vials and then immediately sampled. 


\section{Sample analysis}

The specific electrical conductivity of the water samples was determined using a YSI model 3252 probe connected to a YSI model 3100 conductivity meter. The meter/probe combination was calibrated immediately before sample measurement using 10 and $100 \mu \mathrm{S} \mathrm{cm}-1$ Traceable ${ }^{\circledR}$ Conductivity Standards (Fisher Scientific). All specific conductivity measurements were made using temperature compensation and were reported for the reference temperature of $25^{\circ} \mathrm{C}$. The $\mathrm{pH}$ of the water samples was measured using a Beckman model $200 \mathrm{pH}$ meter and probe after addition of pHISA $^{\text {TM }}$ low-ionic-strength adjustor (Orion) to the sample at a ratio of $1: 100$. The meter/probe combination was calibrated immediately before sample measurement using low-ionic-strength Pure Water ${ }^{\mathrm{TM}} \mathrm{pH}$ buffer solutions 6.97 and 9.15 in order to bracket the sample $\mathrm{pH}$ (Orion). All $\mathrm{pH}$ measurements were made using automatic temperature compensation to the actual temperature of the sample/buffer solution.

Excitation emission matrix spectroscopy was conducted with a Horiba Jobin Yvon Fluoromax-4 Spectrophotometer (Horiba Ltd, Japan) with a xenon light source in a $1 \mathrm{~cm}$ path length quartz cuvette. Excitation data were measured in $10 \mathrm{~nm}$ increments from 240 to $450 \mathrm{~nm}$, and emission data were obtained every $2 \mathrm{~nm}$ from 300 to $540 \mathrm{~nm}$. Data quality controls were conducted by correcting for background $\left(0.2 \mu \mathrm{m}\right.$ filtered Milli-Q ${ }^{\circledR}$ water $)$, Raman scattering and inner-filter effects using absorbance spectra collected between 190 and $1100 \mathrm{~nm}$ with a Genesys 10 Series Spectrophotometer $(1 \mathrm{~cm}$ path length, Thermo Scientific) (McKnight et al. 2001).

The concentration of cellular ATP, a proxy for metabolically viable microbial biomass, was measured using the luciferin/luciferase assay (Lundin 2000). Sample water $(100 \mathrm{ml})$ was filtered through $0.2 \mu \mathrm{m}$ pore-size membranes. Cells trapped on the filter were lysed by adding $200 \mu 1$ of lysis reagent (Biothema Corp.) before reaction with the luciferin/luciferase complex. Illuminance resulting from the reaction of ATP in the presence of the luciferin/luciferase complex was measured using a 20/20n luminometer (Turner BioSystems). Illuminance resulting from the reaction was integrated over a $10 \mathrm{~s}$ period for each measurement. The assay was calibrated using standard addition of ATP. The methodological limit of detection was 0.01 pM ATP.

Procedures for measuring the concentrations of cells in water from the field tests followed the same protocols outlined by Priscu et al. (2013). Briefly, water collected for direct cell counting was fixed with sodium borate-buffered formalin ( $5 \%$ final concentration), 10 or $100 \mathrm{ml}$ of sample was filtered onto $0.2 \mu \mathrm{m}$ pore-size black polycarbonate filters, stained with SYBR Gold (Molecular Probes, Inc.) and enumerated by counting
Table I. The $\mathrm{pH}$ and conductivity for sampled ports at the Whillans Subglacial Lake (SLW) and grounding zone (GZ) drill sites.

\begin{tabular}{llcc}
\hline & Sample & $\mathrm{pH}$ & $\begin{array}{c}\text { Electrical } \\
\text { conductivity } \\
\left(25^{\circ} \mathrm{C} ; \mu \mathrm{Scm}^{-1}\right)\end{array}$ \\
\hline SLW & Input snow & 5.9 & 3.3 \\
& Port 1 & 5.8 & 4.1 \\
& Port 8 & 5.1 & 5.6 \\
& Port 9 & 5.2 & 4.4 \\
$\mathrm{GZ}$ & Water column & 8.1 & 720 \\
& Input snow & 5.1 & 3.5 \\
& Port 1 & 5.1 & 4.4 \\
& Port 8 & 5.1 & 4.7 \\
& Water column & 7.8 & 52700 \\
\hline
\end{tabular}

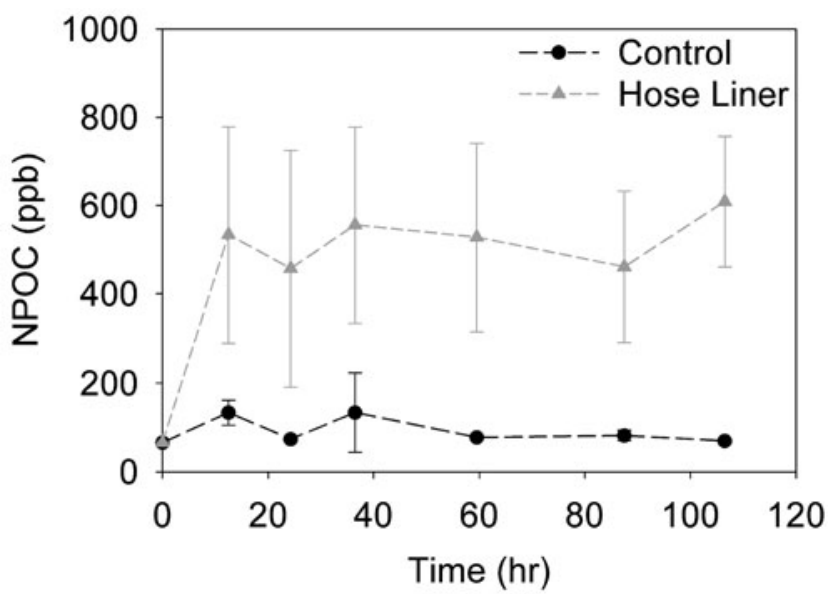

Fig. 3. Non-purgeable organic carbon (NPOC) leaching experiments from the drill hose liner. The values plotted are the means of experimental triplicate incubations; error bars indicate the standard deviation. Controls are bottles incubated, in parallel, with only ultrapure water (18.2 Mohm).

30-60 fields of view or 300 cells using an epifluorescence microscope (Zeiss, Axioskop 50). Samples were run in duplicate and triplicate where sample volume permitted. Filtration blanks were enumerated in parallel.

Non-purgeable organic carbon (NPOC) samples from the hose leaching experiments were analysed with a Sievers Portable 900 total organic carbon (TOC) analyser with an in-line inorganic carbon remover. The NPOC samples from the Niskin bottle leaching tests were measured on a Shimadzu TOC-V using a high-sensitivity oxidation catalyst after acidification and sparging.

A peristaltic pump and sterile tubing were used to concentrate microorganisms on $142 \mathrm{~mm}$ diameter, $0.2 \mu \mathrm{m} \quad$ Supor ${ }^{\circledR}$ membrane filters (Pall Corp.) immediately after sample collection (Achberger et al. 2016). The composition of microbial assemblages in the 

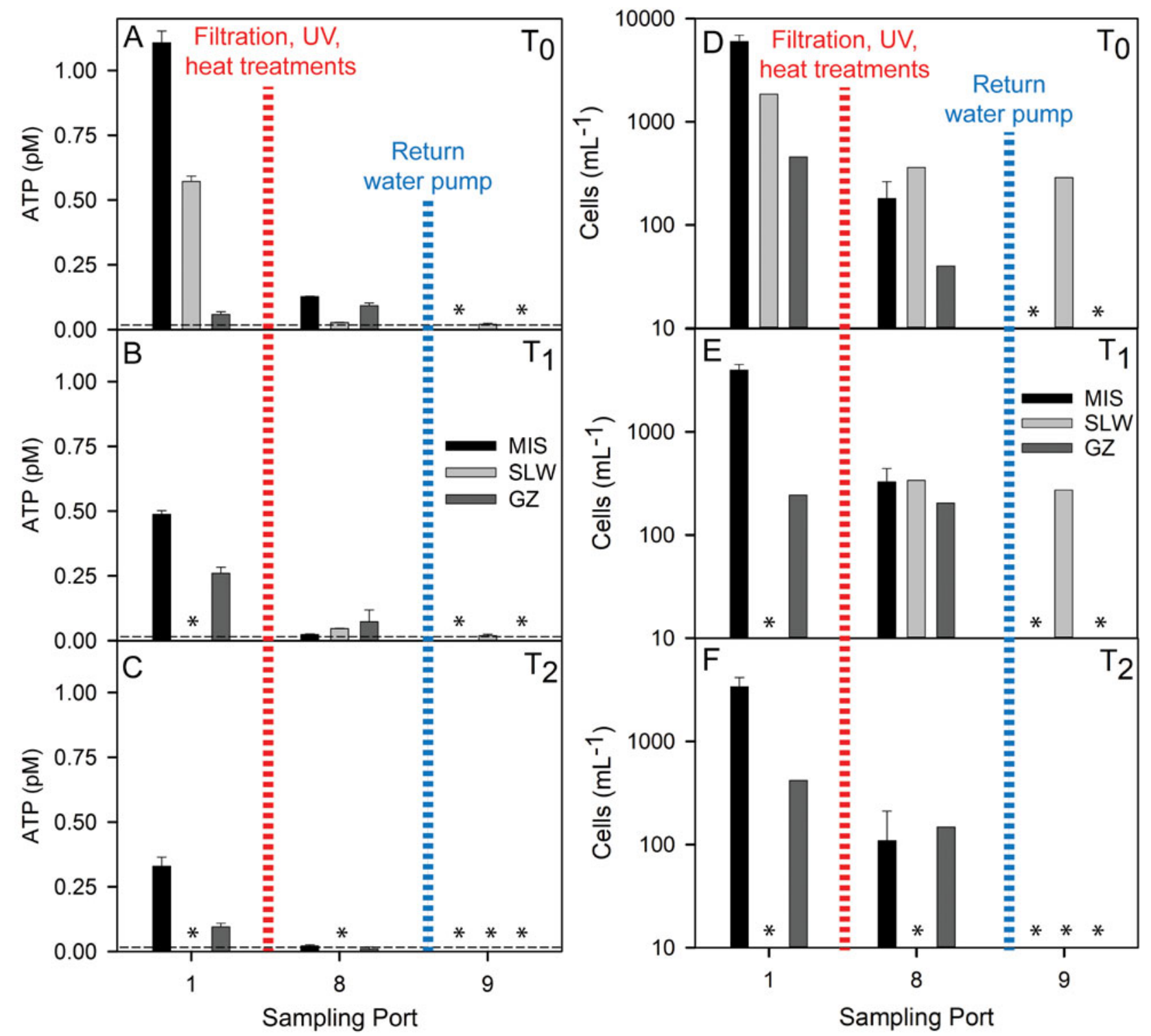

Fig. 4. Adenosine-5'-triphosphate (ATP) levels and cell concentrations from drill sites and sampling ports at the beginning of drilling (a. and d.), halfway through drilling (b. \& e.) and before breakthrough (c. \& f.). Means and, where possible, standard deviations are reported. Horizontal dashed lines represent blank ATP values from three drill sites. Red dashed lines indicate the drill water passed through filtration, ultraviolet (UV) and heat treatments between sampling ports 1 and 8 . Blue dashed lines indicate the drill water returned from the drill head and through the return water pump between sampling ports 8 and 9 . Asterisks denote that samples were not collected. GZ = grounding zone, MIS = McMurdo Ice Shelf, SLW = Whillans Subglacial Lake.

samples was determined by amplification, sequencing and phylogenetic analysis of the 16S rRNA gene's V4 region according to Achberger et al. (2016). Briefly, paired end sequence reads were assembled and parsed using mothur (v1.33.3; Schloss et al. 2009). The data were normalized in order to generate a non-metric multidimensional scaling (NMDS) plot based on Bray-Curtis distance using the Vegan (https://cran.r-project.org/web/packages/ vegan/index.html) and Phyloseq (McMurdie \& Holmes 2013) packages in $R$ (v.3.6.0).

\section{Results}

\section{Geochemistry}

The $\mathrm{pH}$ and conductivity of the input snow and sampling ports at the SLW and GZ field sites were slightly acidic $(\mathrm{pH} \sim 5)$ and ionically dilute $\left(3.3-5.6 \mu \mathrm{S} \quad \mathrm{cm}^{-1}\right)$ (Table I). The $\mathrm{pH}$ and conductivity of the SLW water column were 8.1 and $720 \mu \mathrm{S} \mathrm{cm}^{-1}$, respectively, whereas those of the GZ seawater were 7.8 and $52.7 \mathrm{mS} \mathrm{cm}^{-1}$, respectively. 


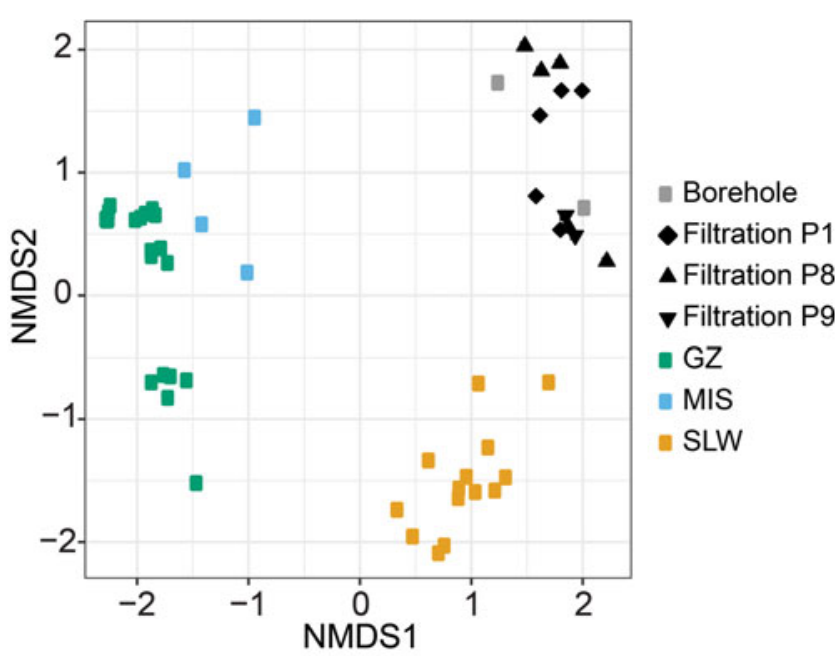

Fig. 5. Non-multidimensional scaling plot of the microbial community compositions at all three drill sites from the water column, sediments and clean access sampling. $\mathrm{GZ}=$ grounding zone, MIS $=$ McMurdo Ice Shelf, $\mathrm{P}=$ port, SLW $=$ Whillans Subglacial Lake

The character of the FDOM was similar between the samples collected from ports 1 and 8 and the borehole before breakthrough (Fig. 2) and differed from that in the SLW water column sample (Fig. 2). Maximum fluorescence was higher in sampling ports 1 and 8 ( 0.24 and 0.36 Raman units $\mathrm{cm}^{-1}$, respectively) and in the borehole (0.19 Raman units $\left.\mathrm{cm}^{-1}\right)$ than in the SLW water column (0.04 Raman units $\left.\mathrm{cm}^{-1}\right)$, and the maximum fluorescence peaks occurred at various excitation and emission wavelengths. Sampling ports 1 and 8 and the borehole cast had maximum excitation at $240-270 \mathrm{~nm}$ and maximum emission at $302-308 \mathrm{~nm}$, while the SLW water column maximum excitation was in the same range as clean access samples, but the emission maximum was at $310 \mathrm{~nm}$. These values denote the different qualities of FDOM between the borehole water and SLW water.

Approximately $500 \mathrm{ppb}$ of NPOC was leached from the drill hose liner into the water at $90^{\circ} \mathrm{C}$ over $107 \mathrm{~h}$ when compared to the control, with almost all NPOC leached within the first $12 \mathrm{~h}$ of incubation (Fig. 3).

\section{Biology}

The ATP level was highest in samples from port 1, ranging from 1.1 to $0.058 \mathrm{pM}$ and averaging $0.41 \mathrm{pM}$ across all time points and drill sites (Fig. 4a \& Supplemental Table I). The ATP concentration from ports 1 to 8 decreased by $72-85 \%$ at all time points and test drill sites (Fig. 4a). One exception is the initial time point $\left(T_{0}\right)$ at the GZ, where ATP increased from port 1 to port
8 by $58 \%$; however, this increase in ATP was not matched by an increase in cell density.

Cell densities were highest in samples from port 1, averaging 2333 cells ml $^{-1}$ (range: 243-5990 cells ml${ }^{-1}$ ) across all time points and drill sites (Fig. 4b \& Supplemental Table I). After passing through the filtration, UV radiation and pasteurization modules, cell density decreased by $16-97 \%$ relative to the concentrations measured at port 1 (Fig. 4b). McMurdo Ice Shelf had the highest average cell density of 4450 cell ml$^{-1}$ at port 1 , while the GZ had the lowest average cell density $\left(373\right.$ cells ml${ }^{-1}$ ) at port 1 . The cell density of port 1 at SLW was only quantified at $\mathrm{T}_{0}\left(1851\right.$ cells $\left.\mathrm{ml}^{-1}\right)$.

Sequences of the 16S rRNA genes obtained from samples of the water column (MIS, SLW, GZ), sediments (SLW, GZ), drill system (MIS and GZ ports 1 and 8, SLW ports 1, 8 and 9) and borehole allowed comparison of the bacteria and archaea present. Statistical analysis of the sequence data revealed that the compositions of the MIS, SLW and GZ communities were significantly different from assemblages in the drilling water or borehole (analysis of variance, $P<0.002$ ). There were few taxa found in the MIS, SLW and GZ drill water (66, 262 and 88, respectively) that were also found in the subglacial environment (Supplemental Fig. 1). According to the NMDS analysis (Fig. 5), the marine (MIS and GZ) drill sites grouped together and were distinct from the freshwater communities in SLW. In contrast, the compositions of microbes associated with the drill system and borehole were similar and formed a loose group in NMDS ordination. DNA extractions from methodological blanks $(n=4)$ showed no visible amplification of the 16S rRNA gene when examined on an agarose gel. Sequencing of these samples resulted in a low number of reads, and they were therefore excluded from further analysis.

\section{Discussion}

The US National Research Council (NRC) provided recommendations for the protection and responsible exploration of Antarctic subglacial aquatic environments, emphasizing that the exploration of Antarctic subglacial aquatic environments should proceed only if environmental stewardship is kept at the forefront of sampling and instrumentation design (National Research Council 2007). Following the publication of the NRC report, the Scientific Committee on Antarctic Research developed a code of conduct based on the NRC recommendations (Doran \& Vincent 2011). These documents guided our approach to constructing, testing and monitoring the clean access system used during hot-water drilling. Construction of the drill and filtration systems (Rack 2016) and laboratory testing of the filtration system (Priscu et al. 2013) have 
been published. Here, we present new data from samples collected during the actual hot-water drilling of three boreholes during two field seasons.

\section{Performance of the clean access system during drilling in Antarctica}

The water source for the hot-water drill contained low microbial biomass (Fig. 4) and was chemically and microbiologically distinct from the subglacial and sub-ice sheet water (Figs 2, 4 \& 5 \& Table I). Antarctic snow provides an excellent source of meltwater for hot-water drilling due to its low concentration of solutes and typically low microbial biomass relative to those measured in the subglacial environment (Fig. 4 \& Table I). The conductivity measurements show that snow was similar to distilled water in terms of ionic strength. The drill hose and plumbing introduced $<\sim 2 \mu \mathrm{S} \mathrm{cm} \mathrm{cm}^{-1}$ of ionic impurities and was significantly less conductive than the SLW water column (Table I) (Christner et al. 2014). The source of the water is easily distinguished with conductivity given the relatively large differences between the drill water and SLW water column. Furthermore, the relative ease of measuring conductivity was used to confirm immediately upon collection that Niskin bottle samples were collected in the lake and not the result of a misfire in the borehole. The $\mathrm{pH}$ of port 1 water was slightly acidic $(\mathrm{pH}=5.1-5.8)$ in contrast to SLW and GZ water, which were 8.1 (Christner et al. 2014) and 7.8 (Table I), respectively, providing another easily measurable parameter that distinguished the borehole from lake water.

The drill water and SLW water column (Vick-Majors et al. 2020) contained FDOM; however, the FDOM in water collected from the clean access ports and borehole water was distinct from that found in the SLW water column samples (Fig. 2). All samples were characterized by amino acid-like fluorescence (tryptophan- or tyrosine-like; e.g. Coble 1996), but samples from port 1, port 8 and the borehole had distinctly different excitation and emission spectra than the SLW water column (Fig. 2), and the water column was lacking the fluorophore detected at $270 / 300 \mathrm{~nm}$ (excitation/ emission). These results show that the FDOM characterized in the SLW water column was not influenced by the drill water composition. Our leaching experiment results show that the new drill hose may leach NPOC into the drill water upon initial use, but that NPOC concentrations reached a consistent value after $12 \mathrm{~h}$ (Fig. 3). Therefore, the NPOC would have leached during the initial drill test at MIS, with minimal potential for NPOC additions at SLW or the GZ. The hose used during drilling operations is produced from a Rilsan PA11 BESNO P40 TLO polyamide resin and extruded as a continuous $1000 \mathrm{~m}$ hose, which eliminates fittings or junctions (Rack et al. 2014). Our leaching experiments represent the worst-case scenario because of the constant incubation temperature at $90^{\circ} \mathrm{C}$ and because the entire liner with exposed cut ends was soaked in the heated water. These experiments indicated that NPOC contamination was low and not introduced to the subglacial aquatic environments we sampled. Monitoring for NPOC inputs is important for maintaining the scientific integrity of the chemical analyses of subglacial aquatic habitats.

The observations and measurements made at our three drill sites show that the combination of filtration, UV irradiance and heat treatment reduced microbial cell concentration and viable biomass (Fig. 4) to levels far below those observed in the subglacial aquatic environments (MIS: $1.1-1.2 \times 10^{8}$ cells $\mathrm{ml}^{-1}$, Vick-Majors et al. 2016; SLW: $1.3 \times 10^{5}$ cells $\mathrm{ml}^{-1}$, Christner et al. 2014; GZ: $2.6 \times 10^{4}$ cells $\mathrm{ml}^{-1}$ ). The initial source water at all three field sites in Antarctica was surface snow, which contains a low abundance of microbial cells (Fig. 4b) compared to the cell concentrations observed in SLW (Christner et al. 2014). The snow melted to prime the drilling system contained cell concentrations $\left(458-5990\right.$ cells ml $\left.^{-1}\right)$ similar to those reported in snow from the South Pole (200-5000 cell ml ${ }^{-1}$; average: $3140 \pm 771 \mathrm{cell} \mathrm{ml}^{-1}$; Carpenter et al. 2000) and from an ice core collected at the West Antarctic Ice Sheet divide (Santibáñez et al. 2018). However, input snow from the MIS test contained 3 and 13 times greater microbial cells than SLW and GZ input snow, respectively, presumably due to the MIS site being closer $(\sim 48 \mathrm{~km})$ to the open ocean (Vick-Majors et al. 2015), as well as terrestrial microbial sources. This is consistent with cell concentrations reported from surface snow collected near coastal Antarctic stations (1000-46 000 cells ml $^{-1}$; Lopatina et al. 2013), from an Arctic glacier on Svalbard (60 000 cells ml $^{-1}$; Sattler et al. 2001) and from Alpine snow cover (9500-20 000 cell mlBauer et al. 2002). The cell concentrations for the water samples that had passed through the filtration system were compared to the measured ATP concentrations and the estimated ATP per cell value was $\sim 2 \times 10^{-19} \mathrm{~mol}$ ATP cell $^{-1}$. The ATP per cell values observed are consistent with low metabolic activity and are an order of magnitude less than intracellular ATP concentrations measured for late stationary-phase marine microorganisms (Hamilton \& Holm-Hansen 1967), but are within the same order of magnitude as intracellular ATP concentrations of groundwater bacteria (Metge et al. 1993). Similar ATP per cell values are documented from bacteria sampled after passing through a domestic water treatment process that contained similar filtration and UV treatments as were used in the current study (Hammes et al. 2008). In summary, the combination of water treatment procedures used in this study reduced 
cells and viable biomass by $16-97 \%$ from the already pristine surface snow used as source water for drilling operations (Fig. 4).

A NMDS ordination analysis indicated that the DNA-based compositions of microorganisms in the drill water from the three sites were similar, whereas the communities in SLW, the marine water cavity (MIS, GZ) and the sediments underlying each were distinctly different (Fig. 5). Specifically, the SLW communities were distinct from those observed under the ice shelf $(P=0.001)$, while the MIS and GZ communities showed the highest degree of similarity $(P=0.009)$. All of the sub-ice water column and sediment compositions inferred from the sequence analysis were found to be highly significantly different from the drilling water and borehole samples (Fig. 5 \& Supplemental Fig. 1). Operational taxonomic units (OTUs) in port 8 water samples at SLW were only rare members of the SLW community (Achberger et al. 2016). The majority of these OTUs in the drill water, but only rarely within SLW, are common in polar environments such as snow and glacial ice, implying that there was little human- or drill system plumbing-associated point sources of contamination (Achberger et al. 2016). When combined into the complete NMDS analysis, the results from all three drill sites corroborate DNA sequence data from borehole water and SLW lake water, which showed that the assemblage of microorganisms present in these samples was significantly different (Christner et al. 2014). Together, these results and those from laboratory tests (Priscu et al. 2013) provide high confidence that the microorganisms and solutes reported in the subglacial water and sediments were not sourced from the drill water or introduced during subglacial access.

\section{Recommendations for microbiologically and chemically clean access to subglacial environments}

Based on the data collected from three subglacial locations in Antarctica, we recommend the following for those projects planning to comply with environmental stewardship guidelines (and to ensure sample integrity) to access subglacial aquatic environments:

1. Instruments, hoses and cables should be cleaned before deployment to the subglacial aquatic environment. The drill hose should be tested for NPOC leaching and flushed with clean, hot water before drilling into subglacial aquatic environments. In addition, all other instruments, cables and hoses going down the borehole for drilling or sampling should be cleaned with $3 \% \mathrm{H}_{2} \mathrm{O}_{2}$ and UV irradiated.

The results from laboratory tests presented here show that the NPOC leached from the hose to the drill water occurred within the first $12 \mathrm{~h}$ (Fig. 3). The results from
Priscu et al. (2013) recommended all instruments and cables be cleaned with a $3 \% \mathrm{H}_{2} \mathrm{O}_{2}$ solution before deployment, which we conducted with a garden spray bottle. A UV collar was installed beneath the operations deck and all hoses, cables and instruments passed through the UV light during deployment. The UV collar was turned off when the instrument or hose was coming up to protect people working on the deck from UV exposure and potential degradation of the hose due to prolonged UV exposure.

2. Samples should be collected and analysed during drilling operations in order to examine the composition of input water to the drill head and borehole. Analysis should include at a minimum microbiological cell counts, cellular viability (e.g. ATP, live/dead stains), NPOC and conductivity in order to evaluate the microbial and chemical cleanliness of the drill water. These on-site analyses provide real-time feedback on filtration system performance and can guide decision-making regarding filter changes or other servicing of the clean access system. While we did not analyse DNA sequence data in the field, the advancement of genomic sequencing technologies now makes it possible to collect these types of data in the field. We recommend that near real-time, DNA-based monitoring methods be incorporated into the suite of analyses conducted during drilling to discriminate between contaminants and native communities of microorganisms. These measurements should be made as a time series, beginning at the onset of drilling and before breakthrough to the subglacial aquatic environment, providing continual feedback on proper operation of the clean access system.

The suite of analyses conducted in the field (cell counts, ATP, conductivity) show that the filtration system was operating properly and cleaned the drill water to levels outlined in Doran \& Vincent (2011) and National Research Council (2007). The NRC report called for drill water or instruments to contain less than a few hundred cells per millilitre, as this was the best available data at the time of the report (National Research Council 2007). Recommendation 7 in the NRC report suggested $\sim 100$ cells $\mathrm{ml}^{-1}$ as a target for cleanliness based on that number of cells being reported in accretion ice overlying Vostok Subglacial Lake (Christner et al. 2006). The cell densities in the drill water from the three sites reported in this study were $40-361 \mathrm{cell} \mathrm{m}^{-1}, 100$ times lower than the cell densities found in SLW (Christner et al. 2014), indicating that our hot-water drilling fluid was within the limits suggested by the NRC report. Based on our results, the NRC report recommendation of $\sim 100$ cells $\mathrm{ml}^{-1}$ remains a reliable target for drill fluid and instrument cleanliness, but 
we stress the importance of molecular identification of the microorganisms as another way of identifying potential contaminants.

3. Plans for subglacial drilling sites should consider prevailing winds with respect to the source snow for drill water. Appropriate camp layout can reduce the exposure of hot-water drilling source water, borehole operations and scientific laboratories to hydrocarbon contamination from generators, camp equipment and aircraft. In addition, the source of the snow should be from an area that is protected from human and mechanical traffic. Antarctic snow is a microbiologically and chemically clean source of water (Figs 2, $4 \& 5 \&$ Table I), but contamination by human activities in the field is inevitable and a relevant concern.

The area around the source snow and melt tank at SLW (Fig. 1) was limited to drill staff in order to avoid contamination of source snow, which worked well at SLW (Fig. 4). However, at the GZ, particles from the rubber tracks of the Case Quadtrack 530 tractors, used at the GZ to stage snow for melting operations, were found in the melt tank water and collected on the $0.2 \mu \mathrm{m}$ filters, reducing the filter lifetime significantly (Priscu, unpublished data 2015).

4. Finally, subglacial aquatic access research projects should incorporate geophysical data on ice thickness and associated overburden pressure in order to ensure that borehole water does not enter the subglacial environment after breakthrough. Such information was used at all of the drill sites described here, creating a pressure differential that caused subglacial water to rise into the borehole. It is important not to draw down the borehole water level to a point that allows lithostatic collapse of the borehole (Tulaczyk et al. 2014). The pressure exerted on SLW by the overlying ice was calculated to produce a borehole water level $\sim 80 \mathrm{~m}$ below the ice surface, based on estimates of ice thickness from multiple sources (Tulaczyk et al. 2014). Thus, we pumped the borehole water level down to $\sim 110 \mathrm{~m}$ below the surface $1 \mathrm{~h}$ before anticipated breakthrough and, upon breakthrough, the water level rose in the borehole by $28 \mathrm{~m}$ in < $1 \mathrm{~min}$ (Tulaczyk et al. 2014). This procedure follows Recommendation 4.6 of the 'Drilling and SAE-Entry' section from the Scientific Committee on Antarctic Research-Subglacial Antarctic Lake Environments (SCAR-SALE) action group code of conduct report (SCAR-SALE report and NRC report, summarized by Doran \& Vincent 2011).

Promoting responsible environmental stewardship is a requirement of the Antarctic Treaty, and collecting samples of subglacial aquatic environments that are verifiably free of surface contamination is necessary for the integrity of scientific investigations. As such, our recommendations provide guidance for minimizing contamination when collecting pristine samples from any subglacial aquatic environments while at the same time ensuring a high level of sample integrity.

\section{Acknowledgements}

We thank P. Adkins and K. Roush for cell counts and F. Rack for details on the clean access system. Logistics were provided by the 139th Expeditionary Airlift Squadron of the New York Air National Guard, Kenn Borek Air and Antarctic Support Contractor, managed by Lockheed-Martin. Hot-water drill support was provided by the University of Nebraska-Lincoln, directed by F. Rack and D. Duling (chief driller), with D. Blythe, J. Burnett, C. Carpenter, D. Gibson, J. Lemery, A. Melby and G. Roberts. We grateful to the drillers for all their support and efforts during the two field seasons. We thank two anonymous reviewers who improved the manuscript. This is C-DEBI contribution \#528.

\section{Author contributions}

All authors planned and participated in sample collection, ABM, TJV-M, MLS, MT and AMA processed samples and all authors analysed data and contributed to writing the manuscript.

\section{Financial support}

The Whillans Ice Stream Subglacial Access Research Drilling (WISSARD) project was funded by National Science Foundation grants (0838933, 1346250, 1439774 to JCP; 0838941 to BCC) from the Division of Polar Programs. Partial support was provided by graduate fellowships from the NSF-IGERT Program (0654336) and NSF-Center for Dark Energy Biosphere Investigations (ABM), as well as a dissertation grant from the American Association of University Women (TJV-M). The Fig. 1 inset map was provided by the Polar Geospatial Center and Brad Herried under NSF-PLR (1043681).

\section{Details of data deposit}

The data presented in this manuscript can be found on the Microbial Antarctic Resource System (http://mars. biodiversity.aq) and the excitation emission matrix spectroscopy can be found on the OpenFluor database (https://openfluor.lablicate.com).

\section{Supplemental material}

A supplemental table and figure will be found at https:// doi.org/10.1017/S0954102020000231. 


\section{References}

Achberger, A.M., Christner, B.C., Michaud, A.B., Priscu, J.C., Skidmore, M.L. \& Vick-MaJors, T.J. 2016. Microbial community structure of Subglacial Lake Whillans, West Antarctica. Frontiers in Microbiology, 7, 10.3389/fmicb.2016.01457.

Alekhina, I.A., Ekaykin, A., Moskvin, A. \& Lipenkov, V. 2018. Chemical characteristics of the ice cores obtained after the first unsealing of Subglacial Lake Vostok. In Siegert, M.J., JAMIESON, S.S.R. \& White, D.A., eds. Exploration of subsurface Antarctica: uncovering past changes and modern processes. Special Publication of the Geological Society of London, No. 461, 187-196.

Bauer, H., Kasper-Giebl, A., Löflund, M., Giebl, H., Hitzenberger, R., ZibuschKA, F., et al. 2002. The contribution of bacteria and fungal spores to the organic carbon content of cloud water, precipitation and aerosols. Atmospheric Research, 64, 10.1016/S0169-8095(02)00084-4.

Bentley, M., Christofferson, P., Hodgson, D.A., Smith, A., Tulaczyk, S.M. \& Le BrocQ, A.M. 2013. Subglacial lake sediments and sedimentary processes: potential archives of ice sheet evolution, past environmental change, and the presence of life. Geophysical Monograph Series, 192, 83-110.

Bulat, S.A. 2016. Microbiology of the subglacial Lake Vostok: first results of borehole-frozen lake water analysis and prospects for searching for lake inhabitants. Philosophical Transactions of the Royal Society A, 374, 10.1098/rsta.2014.0292.

Carpenter, E.J., Lin, S. \& Capone, D.G. 2000. Bacterial activity in South Pole snow. Applied and Environmental Microbiology, 66, 10.1128/AEM.66.10.4514-4517.2000.Updated.

Christner, B.C., Mikucki, J.A., Foreman, C.M., Denson, J. \& Priscu, J.C. 2005. Glacial ice cores: a model system for developing extraterrestrial decontamination protocols. Icarus, 174, 10.1016/ j.icarus.2004.10.027.

Christner, B.C., Royston-Bishop, G., Foreman, C.M., Arnold, B.R., Tranter, M., Welch, K.A., et al. 2006. Limnological conditions in Subglacial Lake Vostok, Antarctica. Limnology and Oceanography, 51, 2485-2501.

Christner, B.C., Priscu, J.C., Achberger, A.M., Barbante, C., Carter, S.P., Christianson, K., et al. 2014. A microbial ecosystem beneath the West Antarctic ice sheet. Nature, 512, 10.1038/ nature 13667.

CoBLE, P.G. 1996. Characterization of marine and terrestrial DOM in seawater using excitation-emission matrix spectroscopy. Marine Chemistry, 51, 325-346.

Doran, P.T. \& VINCENT, W.F. 2011. Environmental protection and stewardship of subglacial aquatic environments. Geophysical Monograph Series, 192, 149-157.

Engelhardt, H. \& Kamb, B. 1998. Basal sliding of Ice Stream B, West Antarctica. Journal of Glaciology, 44, 223-230.

Engelhardt, H.F., Kamb, B. \& Bolsey, R. 2000. A hot-water ice-coring drill. Journal of Glaciology, 46, 341-345.

Fisher, A.T., Mankoff, K.D., Tulaczyk, S.M. \& Tyler, S.W. 2015. High geothermal heat flux measured below the West Antarctic Ice Sheet. Science Reports, 1, 10.1126/sciadv.1500093.

Gaidos, E., Lanoil, B.D., Thorsteinsson, T., Graham, A., Skidmore, M., HaN, S.K., et al. 2004. A viable microbial community in a subglacial volcanic crater lake, Iceland. Astrobiology, 4, 327-344.

Hamilton, R.D. \& Holm-Hansen, O. 1967. Adenosine triphosphate content of marine bacteria. Limnology and Oceanography, 12, 319-324.

Hammes, F., Berney, M., Wang, Y., Vital, M., Köster, O. \& Egli, T. 2008. Flow-cytometric total bacterial cell counts as a descriptive microbiological parameter for drinking water treatment processes. Water Research, 42, 10.1016/j.watres.2007.07.009.

Lopatina, A., Krylenkov, V. \& Severinov, K. 2013. Activity and bacteria diversity of snow around Russian Antarctic stations. Research in Microbiology, 164, 10.1016/j.resmic.2013.08.005.
Lundin, A. 2000. Use of firefly luciferase in ATP-related assays of biomass, enzymes, and metabolites. Methods in Enzymology Part C, 305, 346-370.

McKnight, D.M., Boyer, E.W., Westerhoff, P.K., Doran, P.T., Kulbe, T. \& ANDERSEN, D.T. 2001. Spectrofluorometric characterization of dissolved organic matter for indication of precursor organic material and aromaticity. Limnology and Oceanography, 46, 10.4319/ lo.2001.46.1.0038.

McMurdie, P.J. \& Holmes, S. 2013. Phyloseq: an $R$ package for reproducible interactive analysis and graphics of microbiome census data. PLoS One, 8, e61217.

Metge, D.W., Brooks, M.H., Smith, R.L. \& Harvey, R.W. 1993. Effect of treated-sewage contamination upon bacterial energy charge, adenine nucleotides, and DNA content in a sandy aquifer on Cape Cod. Applied and Environmental Microbiology, 59, 2304-2310.

Michaud, A.B., Dore, J.E., Achberger, A.M., Christner, B.C., Mitchell, A.C., Skidmore, M.L., et al. 2017. Microbial oxidation as a methane sink beneath the West Antarctic Ice Sheet. Nature Geoscience, 10, 10.1038/NGEO2992.

National Research Council. 2007. Exploration of Antarctic subglacial aquatic environments: environmental and scientific stewardship. Washington, DC: National Academies Press, 162 pp.

Priscu, J.C., Tulaczyk, S., Studinger, M., Kennicutt II, M.C., Christner, B.C. \& Foreman, C.M. 2008. Antarctic subglacial water: origin, evolution, and ecology. In VINCENT, W.F. \& Laybourn-Parry, J., eds. Polar lakes and rivers. Oxford: Oxford University Press, 119-135.

Priscu, J.C., Achberger, A.M., Cahoon, J.E., Christner, B.C., EDWARDS, R.L., Jones, W.L., et al. 2013. A microbiologically clean strategy for access to the Whillans Ice Stream subglacial environment. Antarctic Science, 25, 10.1017/S0954102013000035.

RACK, F.R. 2016. Enabling clean access into Subglacial Lake Whillans: development and use of the WISSARD hot water drill system. Philosophical Transactions of the Royal Society A, 374, 10.1098/ rsta.2014.0305.

Rack, F.R., Duling, D., Blythe, D., Burnett, J., Gibson, D., Roberts, G., et al. 2014. Developing a hot-water drill system for the WISSARD project: 1 . Basic drill system components and design. Annals of Glaciology, 55, 10.3189/2014AoG68A031.

Santibáñez, P., Maselli, O.J., Greenwood, M.C., Grieman, M.M., Saltzman, E.S., McConnell, J.R., et al. 2018. Prokaryotes in the WAIS Divide ice core reflect source and transport changes between Last Glacial Maximum and the early Holocene. Global Change Biology, 24, 10.1111/gcb.14042.

Sattler, B., Puxbaum, H. \& Psenner, R. 2001. Bacterial growth in supercooled cloud droplets. Geophysical Research Letters, 28, 239-242.

Schloss, P.D., Westcott, S.L., Ryabin, T., Hall, J.R., Hartmann, M., Hollister, E.B., et al. 2009. Introducing mothur: open-source, platform-independent, community-supported software for describing and comparing microbial communities. Applied and Environmental Microbiology, 75, 10.1128/AEM.01541-09.

Skidmore, M. 2011. Microbial communities in Antarctic subglacial aquatic environments. Geophysical Monograph Series, 192, 61-81.

Talalay, P.G. \& Gundestrup, N.S. 2002. Hole fluids for deep ice core drilling. Memoirs of National Institute of Polar Research Special Issue, 56, 148-170.

Truffer, M., Motyka, R.J., Harrison, W.D., Echelmeyer, K.A., Fisk, B. \& TUlACZYK, S.M. 1999. Subglacial drilling at Black Rapids, Alaska, USA: drilling method and sample description. Journal of Glaciology, 45, 495-505.

TulaczyK, S., Mikucki, J.A., Siegrried, M.R., Priscu, J.C., Barcheck, C.G., BEEM, L.H., et al. 2014. WISSARD at Subglacial Lake Whillans, West Antarctica: scientific operations and initial observations. Annals of Glaciology, 55, 10.3189/2014AoG65A009. 
Vick-Majors, T.J., Achberger, A.M., Santibáñez, P., Dore, J.E., Hodson, T., Michaud, A.B., et al. 2015. Biogeochemistry and microbial diversity in the marine cavity beneath the McMurdo Ice Shelf, Antarctica. Limnology and Oceanography, 61, 10.1002/lno.10234.

Vick-Majors, T.J., Mitchell, A.C., Achberger, A.M., Christner, B.C., Dore, J.E., Michaud, A.B., et al. 2016. Physiological ecology of microorganisms in Subglacial Lake Whillans. Frontiers in Microbiology, 7, 10.3389/fmicb.2016.01705.
Vick-Majors, T.J., Michaud, A.B., Skidmore, M.L., Turetta, C., Barbante, C., Christner, B.C., et al. 2020. Biogeochemical connectivity between freshwater ecosystems beneath the West Antarctic Ice Sheet and the sub-ice marine environment. Global Biogeochemical Cycles, 34, 10.1029/2019GB006446.

Wadham, J.L., Tranter, M., Skidmore, M., Hodson, A.J., Priscu, J.C., Lyons, W.B., et al. 2010. Biogeochemical weathering under ice: Size matters. Global Biogeochemical Cycles, 24, 10.1029/2009GB 003688. 